\title{
International trade in services: Some evidence on the influence of international servicification of manufacturing
}

\author{
Elżbieta Bombińska
}

\begin{tabular}{|c|c|}
\hline \multicolumn{2}{|r|}{ A B S T R ACT } \\
\hline \multicolumn{2}{|c|}{$\begin{array}{l}\text { Objective: The aim of the article is to discuss the impact of international servicification } \\
\text { of manu-facturing on international trade in services and its modes. }\end{array}$} \\
\hline \multicolumn{2}{|c|}{$\begin{array}{l}\text { Research Design \& Methods: The article is of a descriptive character, based on com- } \\
\text { prehensive literature review. It presents an analytical frameworks of international ser- } \\
\text { vicification of manufacturing (i.e. its concept, constituents and measuring methods) as } \\
\text { well as an overview of main find-ings of selected empirical research on this phenome- } \\
\text { non carried out by WTO, National Board of Trade and OECD. }\end{array}$} \\
\hline \multicolumn{2}{|c|}{$\begin{array}{l}\text { Findings: The analysis shows that services as inputs, outputs as well as in-house activi- } \\
\text { ties within manufacturing firms constitute a key component of manufacturing process } \\
\text { and manu-facturing products. As the globalization progresses, the international dimen- } \\
\text { sion of the servicification of manufacturing, i.e. international servicification, increases. } \\
\text { Interna-tional servicification means that manufacturing sector strongly affects trade in } \\
\text { services and this influence goes far beyond the scope of GATS' modes of supplying ser- } \\
\text { vices. In addition to cross-border transactions and rendering services through the } \\
\text { movement of labour and capital this trade encompasses services embodied in exported } \\
\text { or im-ported goods which are traded indirectly across borders. }\end{array}$} \\
\hline \\
\hline Article type: & \\
\hline & \\
\hline & \\
\hline & \\
\hline
\end{tabular}

\section{Suggested citation:}

Bombińska, E. (2019). International trade in services: Some evidence on the influence of international servicification of manufacturing. International Entrepreneurship Review (previously published as International Entrepreneurship / Przedsiębiorczość Międzynarodowa), 5(2), 107-117. https://doi.org/10.15678/IER.2019.0502.07 


\section{INTRODUCTION}

Services have occupied a dominant place in most economies for a long time and they are indisputably perceived as an important feature of the global economic landscape (Francois, Manchim, \& Tomberger, 2015). The recent research on measuring trade in terms of the value added to products has highlighted an even more significance of services in home economies as well as in international trade. It has also thrown a light on the growing interrelationship between services and manufacturing activities described in the term of 'servicification of manufacturing'. Essentially, the servicification of manufacturing can be defined as the fact that manufacturing companies increasingly buy, produce and sell services. All these activities could either be run at home or internationally which gives the basis for distinguishing a specific type of servicification - international servicification.

The main objective of the papers is to discuss the impact of international servicification of manufacturing on international trade in services. Because the article is mainly of a theoretical and conceptual nature, the basic research method is a comprehensive literature review. The paper consists of two main parts devoted successively to: analytical frameworks of international servicification of manufacturing (i.e. its concept, constituents and measuring methods) and on overview of main findings of selected empirical research on this phenomenon carried out by WTO, National Board of Trade and OECD. The paper concludes in the recapitulation of the main findings resulted from the conducted study.

\section{ANALYTICAL FRAMEWORKS OF INTERNATIONAL SERVICIFICATION OF MANUFACTURING}

\section{Servicification of manufacturing: the concept and constituents}

The term of 'servicification of manufacturing' has been introduced by National Board of Trade (2010) and it has been developed in a number of studies in recent years (such as Baldwin, Forslid, \& Ito, 2015; Lodefalk, 2013, 2014, 2016; National Board of Trade, 2012, 2016; Nordås, 2010; Nordås \& Kim, 2013). In general the servicification means the growing importance of services in manufacturing activities resulting in the fact that the manufacturing companies became ever more dependent on services and many manufacturing products, especially high value ones, can now be perceived 'as complex bundles or hybrids of goods and services interactions' (Cernat \& Kutlina-Dimitrova, 2014, p.7). Servicification is defined briefly and simply by National Board of Trade (2016) as the fact that manufacturing increasingly buys, produces and sells services. Hence the phenomenon of servicification covers three constituents displayed in table 1.

The first component of the servicification - buying services - is more intensive use of services inputs by manufacturing firms. Services are (and always have been) a central part of manufacturing operations in every stage of production. Case studies show that even relatively small manufacturing companies use about 40 types of external services to carry out their activities (National Board of Trade, 2010). The observed increase in the use of services inputs by manufacturing firms has its two primary causes. First, it is closely connected to the continuing trend of outsourcing that aims at the separation of services functions in manufacturing from core production functions. As a result services previously produced in-house by manufacturing companies are now purchased externally as inputs. For Baldwin (Baldwin et al., 2015) observation of this trend became the 
basis for the statement that that servicification may partly be a 'statistical phenomenon'. Secondly, more intensive use of services inputs by manufacturing enterprises is associated with the development of global value chains (Baldwin \& Lopez-Gonzalez, 2015). Services are perceived as the 'glue' in global value chains (Low, 2013) as geographically split companies need services such as transport, communication, logistics, finance, etc. which could link their manufacturing operations across countries.

Table 1. Components of servicification of manufacturing

\begin{tabular}{|l|l|}
\hline $\begin{array}{l}\text { Buying } \\
\text { services }\end{array}$ & $\begin{array}{l}\text { - the growth in the use of services inputs by manufacturing firms } \\
\text { - services as external inputs } \\
\text { - services embodied in products }\end{array}$ \\
\hline $\begin{array}{l}\text { Producing } \\
\text { services }\end{array}$ & $\begin{array}{l}\text { - the increase in provision of support services (such as R\&D, design, distribution, logis- } \\
\text { tics, marketing, sales, after-sale services, IT, back-office and management) within } \\
\text { manufacturing firms } \\
\text { - services as in-house inputs } \\
\text { - services embodied in products }\end{array}$ \\
\hline $\begin{array}{l}\text { Selling } \\
\text { services }\end{array}$ & $\begin{array}{l}\text { - the growth of services sold bundled with goods } \\
\text { - services as outputs } \\
\text { - services embedded in products }\end{array}$ \\
\hline
\end{tabular}

Source: own study.

The second component of servicification is in-house provison of services within manufacturing firms. It can generally be seen as an alternative to buying services as the same service can either be outsourced or performed in-house. The way the firm servicifies makes or buys - depends on its decisions on whether to internalise a particular activity or keep it external. Among the main factors influencing this decision can be mentioned i.a.: costs factors, the will to have core strategic functions in the firm (e.g. R\&D, sales and operations planning, strategic procurement), the need of having service on a continuous basis and with a certain degree of control over it supply, access to qualified employees.

The last component of servicification in manufacturing - initially textualized by Vandermerwe and Rada (1988) as "servitisation" - is the growth of the sales of services which are bundled with goods. Manufacturing companies use services as outputs for many reasons, e.g. to increase the value of products to consumers, to differentiate products from competitors, customize, upgrade and prolong offers (Baines \& Lightfoot, 2013; Cusumano, Khal, \& Suarez, 2015; Oliva \& Kallenberg, 2003). They do it at different stages of sales and after-sales relations with the customer (e.g. installation services, repair services, maintenance services), usually using service as a complement but also as a substitute for a manufacturing product (e.g. firms lease products rather than sell them).

Servicification of manufacturing causes that manufacturing merchandise can no longer be seen as only tangible product, but rather as a mix of goods and services. For analytical and measurement purposes the key is the ability to extract the value of services from this 'manuservice box'. Research on these issues led to development of the concept of 'embodied' and 'embedded' services (Drake-Brockman \& Stephenson, 2012; Pasadilla \&Wirjo, 2014). Embodied services are those that constitute an input into the manufacture of a good meanwhile the embedded services pose an input into the sale of a good. The key difference between these two groups of services is the possibility to separate them from the product: it only occurs in a case of embedded services. 


\section{International servicification}

The servicification of manufacturing is not a purely domestic phenomenon but it also has international dimensions that occur in all of its three components (Figure 1). International servicification in terms of 'buying' takes place if services inputs are purchased abroad (offshore sourcing) or they are derived from a locally established affiliate of a foreign company. In a case of 'producing' component international attribution of servicification occurs in two cases, too. First, when a domestic manufacturing company processes goods inputs sent by a foreign company. Secondly, if in-house provision of services takes place within manufacturing affiliate of a foreign company. Finally international servicification occurs in its 'selling' component, when manufacturing products together with embedded services are exported.

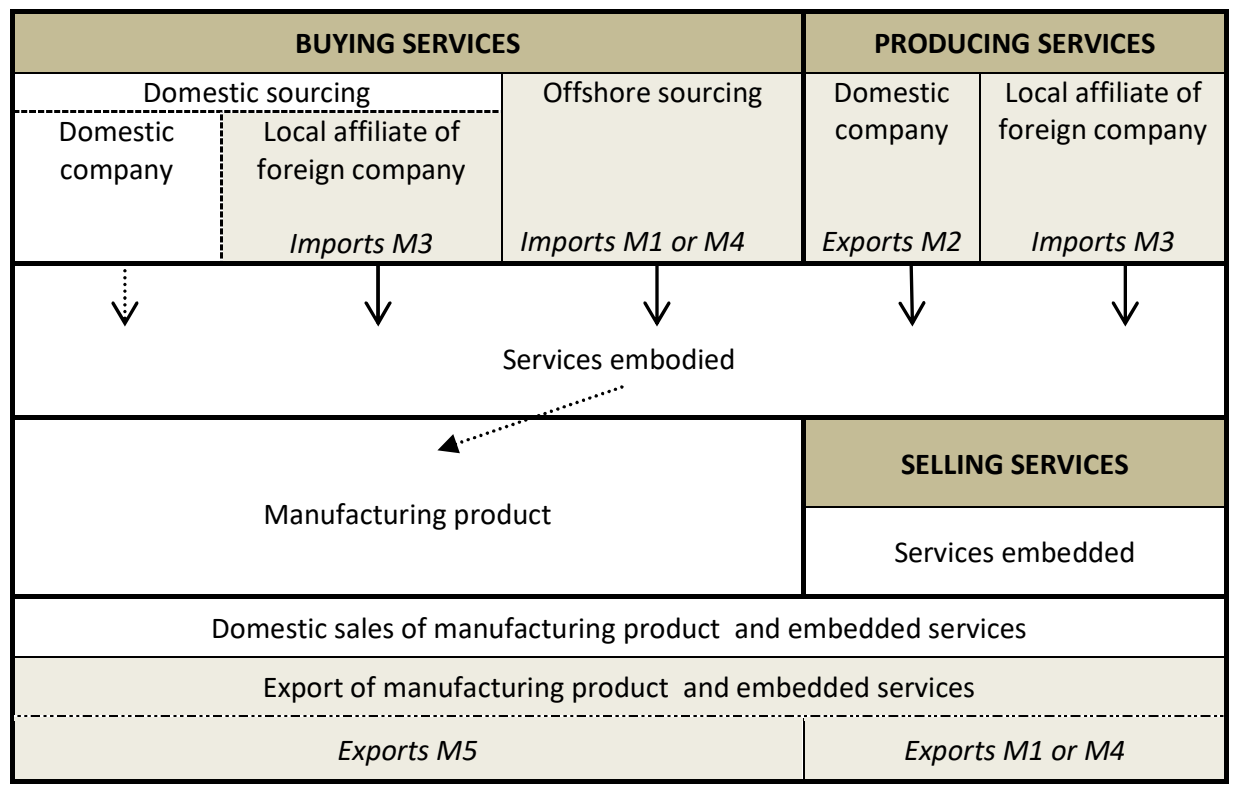

Figure 1. Trade in services effects of international servicification Notes: Grey shaded cells - international servicification components. In italics - trade direction (ex-ports/imports) and modes of service supply (M1 - cross border supply; M2 - consumption abroad; M3 - commercial presence; M4 - presence of natural persons; M5 - indirect trade in services). Source: own elaboration.

International servicification strongly affects trade in services - all of the four modes of service supply set down by GATS (Figure 1). But, additionally, it results in a new mode of international trade in services, indirect trade, named 'Mode 5' (Antimiani \& Cernat, 2018). In this mode services are provided through the cross-border movement of manufacturing goods and it encompasses services which are inseparable part of manufacturing good i.e. services embodied (both external and in-house inputs) as well as part of embedded services which are not charged for directly but sold in a package with a product. 


\section{Methods of measuring international servicification}

The international servicification of manufacturing measurement methods are based on the assessing the value of services both embodied and embedded in manufacturing products. For 'buying' and 'selling' components of servicification - which encompass services supplied on contractual basis - this value is evaluated with the use of inter country input-output tables (ICIO) by looking at the share of value-added originating in services industries. In recent years this method has been widely applied and developed to a high degree due to numerous research on trade in value-added terms and studies on global value chains (such as Bohn, Brakman, \& Dietzenbacher, 2018; Johnson \& Noguera, 2012; Koopman, Wang, \& Wei, 2014; Los, Timmer, \& de Vries, 2016; Miroudot \& Ye, 2018; Nagengast \& Stehrer, 2016).

Notwithstanding this method has some limitations resulting primarily from the lack of current data (the most recent statistics available are those for 2011) and the table's sectoral classification which is based on industrial and not product classification - it could lead to inaccuracy of servicification measurement (Sturgeon, Nielsen, Linden, Gereffi, \& Brown, 2013). Another limitation, especially important for international servicification, arises from the fact that transactions recorded in $\mathrm{ICIO}$ tables are on domestic basis which means that domestic value added comprises the value originating from companies of both domestic and foreign ownership. One of the proposed way of solving this problem - newly displayed by Miroudot and Ye (2018) - is the accounting framework for the decomposition of value-added into domestic, foreign and double counting terms in domestic sales.

Though, the biggest challenge in measuring international servicification remains its 'producing' component because of the statistical shortcomings relating to the value of inhouse provision of services within manufacturing firms (Lodefalk, 2014). To assess this value the share of service employees in manufacturing is often employed (Falk \& Peng, 2013; Miroudot \& Cadestin, 2017; National Board, 2016; Veugelers, 2013).

\section{INTERNATIONAL SERVICIFICATION: SOME EMPIRICAL RESEARCH RESULTS}

Numerous empirical studies on servicification on manufacturing have been carried out in recent years and most of them have taken into account the international dimension of this process, i.e. international servicification. Below are presented the results of three studies conducted by WTO, OECD and Swedish National Board of Trade. The studies have covered differentiated: components of servicification, research groups and researched periods (but not longer than to 2011); also the employed measuring methods and databases have been different however service value-added analysis has posed the common essential research method. Although the previously mentioned limitations of the existing measuring methods and above all - despite huge data scarcity all the research lead to the conclusion that international servicfication increases and, consequently, services embodied or embedded in manufacturing products play a systematically growing role in international trade in services. 


\section{WTO}

The research of Lanz and Maurer (2015), conducted for the years 1995-2008, cover only one element of international servicification of manufacturing, namely foreign services value added content of gross domestic merchandise exports. The research results prove that servicification of manufacturing is substantial both in developed and developing countries: in 2008 services value added content in manufacturing exports of these groups of countries amounted to $33 \%$ and $26 \%$ respectively. Although in both groups domestic sourcing of services made up the majority of the total services value added content, international servicifiaction component share was meaningful, adding up to, on average, about $33 \%$ in developed countries and about $46 \%$ in a case of developing countries. From 1995 to 2008 international servicification of manufacturing exports had increased by more than $4 \mathrm{pp}$. and $2 \mathrm{pp}$. in developed and developing countries respectively. This growth was accompanied by a smaller increase in domestic sourcing of services in developed countries (1 pp.) and the decline of this component in developing countries' group.

\section{National board of trade}

Compared to Lanz and Maurer, National Board of Trade (National Board, 2016) studies have covered more components of international servicification, longer research period (1995-2011) and the studied group of countries has been limited to EU countries. The main research findings are as follows:

1. Service inputs on average constitute $27 \%$ of the cost share in EU manufacturing of which almost half (13\%) is imported. Thus the EU average import share is low, however there are relatively large differences between individual countries: ranging from $75 \%$ in Ireland and $37 \%$ in Lithuania to $5 \%$ and $8 \%$ in Latvia and UK respectively. Between 1995 and 2000 the share of imported service inputs increased by 5 percentage points, from 8 to $13 \%$.

2. About $42 \%$ of employees in EU manufacturing work in service occupations. Most of them (more than 70\%) are high-skilled service suppliers (managers, professionals and technicians) which means that manufacturing, to a great extent, consist of skillintensive service production. These research results concern the whole group of manufacturing enterprises, without separating the foreign affiliates from it. Therefore they cannot be considered a precise description of 'producing' component of international servicification.

3. Manufacturing companies are important service exporters: country evidence (there is no EU-level data available) show that service exports coming from manufacturers represents in Germany and Sweden 25\%, in Italy 35\% and in Austria and Czech Republic $16 \%$ of total service exports.

4. In 2011 the EU average share of service value added in manufacturing exports amounted to $39 \%$ and it was higher by 3 pp. comparing to 1995 . Cross-country differences in this share were significant, reaching values from $46 \%$ (France) and $44 \%$ (Ireland) to $29 \%$ (Romania) and 33\% (Greece). 


\section{OECD}

OECD studies (Miroudot \& Cadestin, 2017) are probably the most comprehensive research so far, complementing the value-added trade analysis with the less investigated components of servicification such as in-house services and bundles of goods and services. They have covered 1995-2011 as research period, mainly OECD countries as studied group and have used three major data sources i.e.: TIVA database, labour force surveys and ORBIS dataset. The main research findings are as follows:

1. In 2011 services amounted to $35 \%$ of the value added in the world gross manufacturing exports. In all manufacturing industries except from coke and petroleum this share was above $30 \%$ and the highest level (38.4\%) was achieved by chemicals and motor vehicles.

2. All manufacturing industries relied on the same mix of services inputs: distribution and business services represented about one third each share meanwhile the last third was split between transport, finance and other services.

3. Between 1995 and 2011 the services value added in the world gross manufacturing exports had only grown by less than $1 \mathrm{pp}$. More significant increases had such industries as utilities (8pp.), wood products, paper, print and publishing (5pp.). The aggregate results were determined by China and the US, where the services value added had not relevantly changed (a minor decrease for China and slight increase for the US). Nevertheless, there were many countries in which an increase in the share of service value added had been recorded; it was especially impressive in Turkey, Latvia, Iceland (above 10 pp.), Luxembourg, Finland, Russia, New Zealand (above 8pp.).

4. Manufacturing exports tend to rely to a larger degree on services sourcing from abroad. In 2011 all manufacturing industries had higher shares of foreign services value added with meaningful (above 4 pp.) increases in industries such as chemicals, rubber and plastics, ICT and electronics. At the same time domestic services value added in most of the industries was decreasing. With the exception of China and Philippines, all other countries shifted towards foreign services inputs. Particularly high growth (above $8 \mathrm{pp}$.) of foreign services value added in gross manufacturing export was recorded in Ireland, Luxembourg, Poland and Turkey.

5. In 2015 across countries, between $25 \%$ and $60 \%$ of employees in manufacturing firms carried out service support functions and not core manufacturing activities. What's important, since 1995 the share of services employment within manufacturing companies in the researched countries has tended to increase. Core manufacturing activities had a larger share in employment in traditional low-tech manufacturing sectors such as textiles and apparel, wood or non-metallic minerals. Estimates show that expressed in value added - in-house services account on average for about $15 \%$ of gross exports of manufacturing products.

6. Firms involved in the sales both goods and services account for share of total sales and exports up to 69 per cent. 


\section{CONCLUSIONS}

The analysis shows that services as inputs, outputs as well as in-house activities within manufacturing firms constitute a key component of manufacturing process and manufacturing products. As the globalization progresses, the international dimension of the servicfication of manufacturing, i.e. international servicification, increases. This trend is evidenced by a numerous empirical research although international servicification measuring encounters large limitations resulting from statistical data shortcomings and research methods that are still being developed and improved.

International servicification means that manufacturing sector strongly affects trade in services, which goes far beyond the scope of GATS' modes of supplying services. In particular, in addition to cross-border transactions and rendering services through the movement of labour and capital this trade encompasses services embodied in exported or imported goods which are traded indirectly across borders. On the other hand, an adequate supply of services affects the functioning of the manufacturing sector and its export competitiveness.

These interdependencies are important for economic policy, especially industrial as well as trade policies. They cannot consider neither manufacturing nor service activities in isolation but as strongly connected and mutually interacting elements. As the empirical studies show that there are large cross-country differences in international servicification and one common pattern of this phenomenon cannot be found, there is a huge field for further research. They could explore the reasons of the cross-country and industry differences as well as the impact of trade in services liberalisation on competitiveness of manufacturing industries and manufacturing exports.

The issue of servicification of manufacturing and its impact on international trade in services in Poland is relatively rarely studied. To some extent, it is undertaken by publications devoted to value added trading and Poland's participation in global value chains (Ambroziak, 2018a, 2018b; Chilimoniuk-Przeździecka \& Kuźnar, 2016; Kuźnar, 2014, 2017; Nessel, 2015). However, these studies require significant deepening, in particular in terms of the branches of services and directions of trade in services embodied in goods. This would allow an assessment of the real role of services in Polish economy and foreign trade, allowing politicians to more precisely stimulate the development of service industries that have the greatest impact on the competitiveness of industrial exports. This knowledge is also difficult to overestimate in negotiations regarding barriers to trade in goods, which due to the servicification of manufacturing - constitute barriers to trade in services too.

\section{REFERENCES}

Ambroziak, Ł. (2018a). Wartość dodana w handlu zagranicznym nowych państw członkowskich Unii Europejskiej. Warszawa: Oficyna Wydawnicza SGH.

Ambroziak, Ł. (2018b). Znaczenie usług w globalnych łańcuchach wartości krajów Europy Środkowej i Wschodniej. Prace Naukowe Uniwersytetu Ekonomicznego we Wrocławiu, 523, 11-22.

Antimiani, A., \& Cernat, L. (2018). Liberalizing Global Trade in Mode 5: How Much Is It Worth? Journal of World Trade, 52(1), 65-83.

Baines, T., \& Lightfoot, H. (2013). Made to Serve: How Manufacturers Can Compete Through Servitization and Product Service Systems. Wiley. 
Baldwin, R.E., Forslid, R., \& Ito, T. (2015). Unveiling the Evolving Sources of Value Added in Exports. Chiba, Japan: Japan External Trade Organisation, Institute of Developing Economics.

Baldwin, R.E., \& Lopez-Gonzalez, J. (2015). Supply-chain trade: A portrait of global patterns and several testable hypotheses. World Economy, 38(11), 682-1721. https://doi.org/10.1111/twec.12189

Bohn, T., Brakman, S., \& Dietzenbacher, E. (2018). The role of services in globalisation. World Economy, 41(11), 2732-2749. https://doi.org/10.1111/twec.12640

Cernat, L., \& Kutlina-Dimitrova, Z. (2014). Thinking in a box: A 'Mode 5' Approach to Service Trade. Journal of World Trade, 48(6), 1109-1126.

Chilimoniuk-Przeździecka, E., \& Kuźnar, A. (2016). Znaczenie usług w globalnych łańcuchach wartości. Gospodarka Narodowa, 5 (285), 141-156.

Cusumano, M.A., Khal, S.J., \& Suarez, F.F. (2015). Services, Industry Evolution, and the Competitive Strategies of Product Firms. Strategic Management Journal, 36(4), 559-575. https://doi.org/10.1002/smj.2235

Drake-Brockman, J., \& Stephenson, S. (2012). Implications for 21st Century Trade and Development of the Emergence of Services Value Chains. International Centre for Trade and Sustainable Development Working Paper.

Falk, M., \& Peng, F. (2013). The increasing Service Intensity of European Manufacturing. The Service Industries Journal, 33(15-16), 1686-1706. https://doi.org/10.1080/02642069.2011.639872

Francois, J., Manchim, M., \& Tomberger, P. (2015). Services Linkages and the Value Added Content of Trade. World Economy, 38(11), 1631-1808. https://doi.org/10.1111/twec.12307

Johnson, R.C., \& Noguera, G. (2012). Accounting for intermediates: Production sharing and trade in value added. Journal of International Economics, 86(2), 224-236. http://dx.doi.org/10.1016/j.jinteco.2011.10.003

Koopman, R., Wang, Z., \& Wei, S.-J. (2014). Tracing value-added and double counting in gross exports. American Economic Review, 104(2), 459-494. http://dx.doi.org/10.1257/aer.20140883

Kuźnar, A. (2017). Udział Polski w globalnych łańcuchach wartości. Horyzonty Polityki, 8 (22), 49-67.

Kuźnar, A. (2014). Wartość dodana w międzynarodowym handlu usługami. In A. Budnikowski \& A. Kuźnar (Eds.), Nowe procesy w gospodarce światowej. Wnioski dla Polski (pp. 121-134). Warszawa: Oficyna Wydawnicza SGH.

Lanz, R., \& Maurer, A. (2015). Services and global value chains: Some evidence on servicification of manufacturing and services networks. WTO Staff Working Paper, no. ERSD-2015-03. Geneva, Switzerland: WTO. http://dx.doi.org/10.30875/cb789e31-en

Lodefalk, M. (2013). Servicification of manufacturing - Evidence from Sweden. International Journal of Economics \& Business Research, 6(1), 87-113. http://dx.doi.org/ 10.1504/IJEBR.2013.054855

Lodefalk, M. (2014). The role of services for manufacturing firm exports. Review of World Economics, 150(1), 59-82. http://dx.doi.org/10.1007/s10290-013-0171-4

Lodefalk, M. (2016). Temporary expats for exports: micro-level evidence. Review of World Economics, 152(4), 733-772. http://dx.doi.org/10.1007/s10290-016-0254-0

Los, B., Timmer, M.P., \& de Vries, G.J. (2016). Tracing Value-Added and Double Counting in Gross Exports: Comment. American Economic Review, 106(7), 1958-1966. https://doi.org/10.1257/aer.20140883

Low, P. (2013). The role of services in global value chains. Real Sector Working Paper. Hong Kong: Fung Global Institute. 
Miroudot, S., \& Cadestin, C. (2017). Services In Global Value Chains: from Inputs to Value-Creating Activities. OECD Trade Policy Papers, no. 197. Paris, France: OECD Publishing. http://dx.doi.org/10.1787/465f0d8b-en

Miroudot, S., \& Ye, M. (2018). Tracing value-added and double counting in sales of foreign affiliates and domestic-owned companies. MPRA Paper, no. 85723. Munich, Germany: University Library of Munich.

Nagengast, A.J., \& Stehrer, R. (2016). Accounting for the Differences Between Gross and Value Added Trade Balances. World Economy, 39(9), 1276-1306. http://dx.doi.org/10.1111/twec.12401.

National Board of Trade (2010). Servicification of Swedish manufacturing. Stockholm, Sweden: National Board of Trade.

National Board of Trade (2012). Everybody is in Services - The Impact of Servicification in Manufacturing on Trade and Trade Policy. Stockholm, Sweden: National Board of Trade.

National Board of Trade (2016). The Servicification of EU manufacturing. Building Competitiveness in the Internal Market. Stockholm, Sweden: National Board of Trade.

Nessel, K. (2015). Internacjonalizacja usług z perspektywy globalnych łańcuchów wartości. Co mówią liczby?. Studia Ekonomiczne. Zeszyty Naukowe Uniwersytetu Ekonomicznego w Katowicach, 226, 95-108.

Nordås, H. (2016). Services Trade Restrictiveness Index (STRI): The Trade Effect of Regulatory Differences. OECD Trade Policy Papers, No. 189, Paris: OECD Publishing. http://dx.doi.org/10.1787/5jlz9z022plp-en

Nordås, H., \& Kim, Y. (2013). The role of services for competitiveness in manufacturing, OECD Trade Policy Papers, No. 148, Paris: OECD Publishing. https://doi.org/10.1787/18166873

Oliva, R., \& Kallenberg, R. (2003). Managing the Transition from Products to Services. International Journal of Service Industry Management, 14(2), 160-172. http://dx.doi.org/10.1108/09564230310474138

Pasadilla, G.O., \& Wirjo, A. (2014). Services and Manufacturing: Patterns of Linkages (Policy Brief APEC). Singapore: APEC Policy Support Unit.

Sturgeon, T., Nielsen, P.B., Linden, G., Gereffi, G., \& Brown, C. (2013). Direct Measurement of Global Value Chains: Collecting Product- and Firm-Level Statistics on Value Added and Business Function Outsourcing and Offshoring. In: Mattoo, A., Wang, Z., \& Wei, S.-J. (Eds.), Trade in Value Added: Developing New Measures of Cross-Border Trade (pp. 291-321). London: Centre for Economic Policy Research and the World Bank.

Vandermerwe, S., \& Rada, J. (1988). Servitization of business: Adding value by adding services. European Management Journal, 6 (4), 314-324.

Veugelers, R. (2013). Trends, Challenges and Prospects for Manufacturing in Europe. In: R. Veugelers (Ed.), Manufacturing Europe's Future (pp. 7-44), Bruegel Blueprint Series, Vol. 21, Brussels: Bruegel. 


\section{Author}

\section{Elżbieta Bombińska}

Associate professor, Ph.D. in economics. Works at the Department of International Trade, Cracow University of Economics (Poland). Her research interests focus on international economics, international trade in services, foreign direct investments and multinational corporations.

Correspondence to: Elżbieta Bombińska, PhD, Cracow University of Economics, Department of International Trade, ul. Rakowicka 27, 31-510 Kraków, Poland, e-mail: bombinse@uek.krakow.pl ORCID (1) http://orcid.org/0000-0002-0929-0150

\section{Acknowledgements and Financial Disclosure}

This article is financed from the funds allocated to the Cracow University of Economics in the framework of grants for maintaining research potential.

\section{Copyright and License}

(ㄷ) (1) $\odot$

This article is published under the terms of the Creative Commons

Attribution - NoDerivs (CC BY-ND 4.0) License

http://creativecommons.org/licenses/by-nd/4.0/

\section{Published by the Centre for Strategic and International Entrepreneurship - Krakow, Poland}

The journal is co-financed in the years $2019-2020$ by the Ministry of Science 
